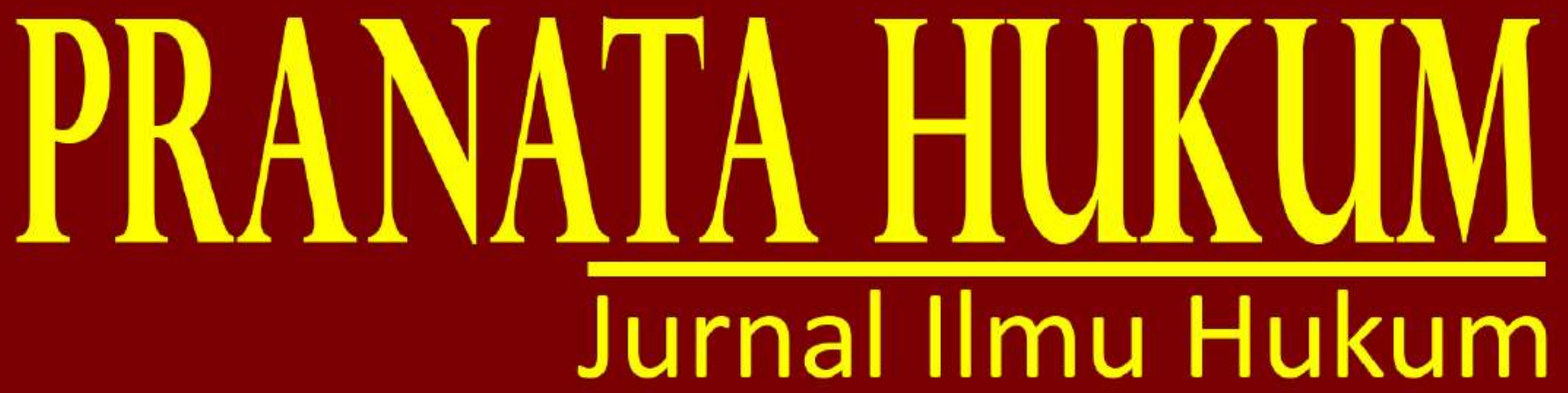

e-ISSN 2685-3213 | p-ISSN 1907-560X

SINERGITAS PEMERINTAHAN DESA DALAM PEMBENTUKAN PERATURAN DESA Anggalana

PENYELESAIAN SENGKETA PERBANKAN BERKAITAN DENGAN PERLINDUNGAN KONSUMEN Dian Herlambang, Muhammad Ridho Wijaya

ANALISIS KOMPARASI ANTARA PERLINDUNGAN PATEN BIASA DENGAN PATEN SEDERHANA BERDASARKAN UNDANG-UNDANG PATEN

Erlina, Melisa Safitri

KONSEPSI NEGARA HUKUM PANCASILA DAN IMPLEMENTASINYA DI INDONESIA Tubagus Muhammad Nasarudin

ANALISIS KEBIJAKAN PEMUNGUTAN RETRIBUSI PELAYANAN PERSAMPAHAN KEBERSIHAN DALAM RANGKA PENINGKATAN PENDAPATAN ASLI DAERAH DI KOTA BANDAR LAMPUNG Pertiwi Agustina RA, Lintje Anna Marpaung, Herlina Ratna Sumbawa Ningrum

ANALISIS KEDUDUKAN PERATURAN DESA PASCA PENGESAHAN UNDANG-UNDANG NOMOR 6 TAHUN 2014 TENTANG DESA DI DESA BADRAN SARI DAN NAMBAH REJO KABUPATEN LAMPUNG TENGAH

Baharudin, Indah Satria, Ramanda Ansori

FANATISME DAN EKSISTENSI NILAI-NILAI DEMOKRASI KADER NAHDLATUL ULAMA KOTA METRO PADA PILPRES 2019

Hendra Irawan, Ika Selviana

PERLINDUNGAN HUKUM TERHADAP PEMENANG LELANG BARANG RAMPASAN NEGARA BERUPA KENDARAAN RODA DUA YANG DIEKSEKUSI DENGAN CARA LELANG OLEH KEJAKSAAN

Okta Vianus Puspa Negara, Zainab Ompu Jainah, S. Tri Herlianto

ANALISIS PERTANGGUNGJAWABAN PELAKU TINDAK PIDANA MENGGANDAKAN SURAT PALSU UNTUK BEKERJA DI PT. GREAT GIANT PINEAPPLE HUMAS JAYA

Helmi Rangkuti, Ketut Seregig, Tami Rusli

MAGISTER HUKUM

UNIVERSITAS BANDAR LAMPUNG

\begin{tabular}{c|c|c|c|l}
$\begin{array}{c}\text { PRANATA } \\
\text { HUKUM }\end{array}$ & $\begin{array}{c}\text { Volume } \\
15\end{array}$ & $\begin{array}{c}\text { Nomor } \\
1\end{array}$ & $\begin{array}{c}\text { Halaman } \\
1-119\end{array}$ & $\begin{array}{l}\text { Bandar } \\
\text { Lampung } \\
\text { Januari } 2020\end{array}$ \\
\hline
\end{tabular}




\section{PRANATA HUKUM}

Jurnal Ilmu Hukum

Magister Hukum

Universitas Bandar Lampung

Terbit Pertama Kali, Juli 2006

Terbit Dua Kali Setahun, Setiap Januari dan Juli

EDITOR IN-CHIEF

Prof. Dr. Lintje Anna Marpaung, S.H., M.H

EDITORIAL BOARDS MEMBERS

Dr. Bambang Hartono, S.H., M.Hum

Dr. Tami Rusli, S.H., M.Hum

Dr. Erlina B, S.H., M.H

Dr. Zainab Ompu Jainah, S.H., M.H

Dr. Zulfi Diane Zaini, S.H., M.H

MANAGING EDITOR

Indah Satria, S.H., M.H

ASSISTANT EDITORS

Yulia Hesti, S.H., MH

Shany Carolina Mawuntu

\section{PENYUNTING AHLI (MITRA BESTARI)}

Prof. Dr. I Gusti Ayu Ketut Rachmi Handayani, S.H., M.M (Universitas Sebelas Maret)

Prof. Dr. I Gede A.B Wiranata, S.H., M.H (Universitas Lampung)

Dr. Nurhadiantomo, S.H., M.Hum (Universitas Muhammdiyah Surakarta)

Dr. Erina Pane, S.H., M.H (UIN Lampung)

\section{Alamat: \\ Kampus B Universitas Bandar Lampung}

Jl. Z.A Pagar Alam No.89 Labuhan Ratu, Bandar Lampung 35142

Telp: 0721-789825 Fax: 0721-770261

Email: jurnal.mh@ubl.ac.id

Jurnal PRANATA HUKUM dimaksudkan sebagai media komunikasi ,edukasi dan informasi ilmiah bidang ilmu hukum. Sajian dan kemasan diupayakan komunikatif melalui bahasa ilmiah.

Redaksi mengundang semua elemen masyarakat ,baik civitas akademika, praktisi , lembaga masyarakat, maupun perorangan yang berminat terhadap bidang hukum untuk berpartisipasi mengembangkan gagasan, wawasan, dan pengetahuan melalui tulisan untuk dimuat dalam jurnal ini. Melalui PRANATA HUKUM diharapkan terjadi proses pengembangan bidang hukum sebagai bagian penting dari rangkaian panjang proses memajukan masyarakat bangsa 


\title{
PENYELESAIAN SENGKETA PERBANKAN BERKAITAN DENGAN PERLINDUNGAN KONSUMEN
}

\author{
Dian Herlambang1, Muhammad Ridho Wijaya²
}

\begin{abstract}
The economy is one aspect of human life that is vulnerable to offense and even evil in it. As the development of the electronic world and the turnover of global money increasingly fast, demanded that people connect with other parties that are banking institutions to manage the money he has. It can be utilized by the person who is not responsible for dredge profit by utilizing the weakness of the banking system both using conventional and electronic media use. The problem in this article is how the banking dispute resolution mechanism relates to consumer protection? The approach to the problem used is normative juridical with the literature study method. The results showed that the banking dispute resolution mechanism in relation to consumer protection can be through two banking dispute resolution mechanisms, namely internal dispute resolution and external dispute resolution of the dispute.
\end{abstract}

\section{Keywords: dispute resolution, banking, consumer protection}

\section{PENDAHULUAN}

Perekonomian merupakan salah satu aspek kehidupan manusia yang rentan terjadi pelanggaran bahkan kejahatan di dalamnya. Seiring perkembangan dunia elektronik serta perputaran uang global semakin cepat, menuntut manusia berhubungan dengan pihak lain yakni lembaga perbankan guna mengelola uang yang ia miliki. Hal tersebut bisa saja dimanfaatkan oleh orang yang tidak bertanggung jawab untuk mengeruk keuntungan dengan memanfaatkan kelemahan sistem perbankan baik menggunakan hal konvensional maupun menggunakan media elektronik.

Menarik mundur beberapa tahun lalu, terdapat pula kejahatan perbankan misalnya kasus Bank Century dan yang menjadi korban adalah nasabah penyimpan dana, dan rakyat secara keseluruhan karena selain modal dari bank tersebut juga mendapat pinjaman dari Bank Indonesia yang sesungguhnya uang tersebut adalah uang rakyat. Dengan demikian perlu dilakukan identifikasi terhadap korban dari kejahatan ekonomi dalam bidang perbankan sehingga

1 Dosen Institut Informatika dan Bisnis Darmajaya, Dianherlambang03@gmail.com

2 Mahasiswa Pascasarjana Fakultas Hukum Universitas Lampung, ridhowijayaa@gmail.com 
dilakukanlah kebijakan guna melindungi hak konsumen perbankan agar tercipta kedamaian dan kesejahteraan. ${ }^{3}$

Berbicara mengenai perlindungan konsumen, maka berbicara mengenai hak asasi manusia dalam hal perlindungan. Konsep hak asasi manusia, dimana terjadi praktek eksploitasi dari pihak yang kuat kepada pihak yang lemah, dalam hal ini pelaku usaha ditempatkan sebagai kelompok masyarakat yang kuat, sedangkan konsumen menjadi pihak yang lemah yang selalu menjadi sasaran eksploitasi oleh pelaku usaha. Perlindungan konsumen sendiri secara internasional telah diakui oleh Perserikatan Bangsa-Bangsa (PBB) dengan adanya Konvensi serta pedoman mengenai perlindungan konsumen dituangkan dalam United Nation Guidelines on Consumer Protection (UNGCP). ${ }^{4}$

Perlindungan konsumen di Indonesia telah diatur dalam Undang-Undang Nomor 8 Tahun 1999 tentang Perlindungan Konsumen (UU PK), hal ini menjadi tonggak penting dunia konsumen di Indonesia dengan diakomodirnya hak-hak konsumen yang dilanggar. Lebih jauh, diatur pula perlindungan konsumen di Indonesia dengan dikeluarkannya Undang-Undang Nomor 21 Tahun 2011 tentang Otoritas Jasa Keuangan (OJK). Dengan dibentuknya suatu lembaga pengawas keuangan di Indonesia, mengindikasikan bahwa pemerintah serius untuk mencegah adanya kejahatan yang dilakukan oleh lembaga keuangan dalam hal ini adalah bank sehingga hak konsumen dapat terlindungi dengan baik. Maka, berdasarkan penjelasan di atas maka yang menjadi bahan kajian pada tulisan ini ialah bagaimana mekanisme penyelesaian sengketa perbankan berkaitan dengan perlindungan konsumen.

Berdasarkan pemaparan latar belakang tersebut, maka yang menjadi permasalahan dalam penulisan ini adalah bagaimanakah mekanisme penyelesaian sengketa perbankan berkaitan dengan perlindungan konsumen. Penelitian ini bersifat yuridis normatif dengan cara mengkaji bahan pustaka atau bahan sekunder sebagai bahan dasar meneliti serta digunakan pula metode studi kepustakaan. Penulisan ini bertujuan untuk memberikan pemahaman kepada pembaca mengenai mekanisme penyelesaian sengketa perbankan yang dapat dilakukan oleh konsumen berkaitan dengan perlindungan konsumen serta diharapkan menjadi bahan rujukan pembelajaran bagi akademisi maupun praktisi hukum.

${ }^{3}$ Rachmawati Apriliana Puspitasari dan Nyoman Satyayudha Dananjaya. Perlindungan Terhadap Korban Kejahatan Ekonomi di Bidang Perbankan. Kertha Wicara: Journal Ilmu Hukum, Vol. 3 (2), 2014, hlm. 2.

${ }^{4}$ Inosentius Samsul. Perlindungan Konsumen Jasa Keuangan Pasca Pembentukan Otoritas Jasa Keuangan (OJK). Jurnal Negara Hukum, Vol. 4 (2), 2013, hlm. 154. 


\section{PEMBAHASAN}

\section{a. Konsep Perlindungan Konsumen}

Pasal 1 angka (1) UU PK menyatakan bahwa perlindungan konsumen adalah segala upaya yang menjamin adanya kepastian hukum untuk memberi perlindungan kepada konsumen. UU PK merupakan payung dari semua peraturan perundang-undangan yang terkait perlindungan konsumen. UU PK juga mengakui Undang-Undang lain yang akan muncul kemudian sebagai bagian dari hukum perlindungan konsumen. UU OJK merupakan salah satu contoh Undang-Undang yang lahir 12 tahun setelah UU PK yang akan memperkuat sistem hukum perlindungan konsumen.

Kewenangan Otoritas Jasa Keuangan (OJK) dan Bank Indonesia (BI) dalam mengatur dan mengawasi lembaga perbankan di Indonesia pasca diberlakukannya UU No. 21 Tahun 2011 tentang Otoritas Jasa Keuangan. Dengan diberlakukannya UU No. 21 Tahun 2011, maka kewenangan BI dalam mengatur dan mengawasi lembaga perbankan di Indonesia dialihkan ke OJK. Intinya, kewenangan BI dalam mengatur dan mengawasi lembaga perbankan di Indonesia lebih kepada kebijakan macroprudential, yaitu kebijakan yang memiliki tujuan utama untuk memelihara stabilitas keuangan secara keseluruhan dalam rangka mengurangi risiko dan biaya krisis sistemik; sedangkan kewenangan OJK dalam mengatur lembaga perbankan lebih bersifat microprudential yang terfokus pada kesehatan institusi keuangan secara individual seperti pengaturan dan pengawasan kelembagaan, kesehatan, aspek kehati-hatian, dan pemeriksaan bank. ${ }^{5}$

Perlindungan konsumen dalam UndangUndang No. 21 Tahun 2011 tentang Otoritas Jasa Keuangan, mencakup perlindungn konsumen yang lebih kompleks dan lengkap. Dengan cakupan yang semakin luas maka jangkauan tugas, wewenang dan tanggungjawab perlindungan konsumen oleh Otoritas Jasa Keuangan juga semakin luas dibidang jasa keuangan. Dalam Pasal 4 huruf (c) Undang-Undang No. 21 Tahun 2011 tentang Otoritas Jasa Keuangan, tujuan dibentuknya lembaga Jasa Keuangan yakni Otoritas Jasa Keuangan dibentuk agar keseluruhan kegiatan didalam sektor jasa keuangan mampu melindungi kepentingan konsumen dan masyarakat.

Upaya memberikan dukungan terhadap peningkatan kualitas layanan konsumen di sektor jasa keuangan, Otoritas Jasa keuangan telah menerbitkan beberapa ketentuan yang dijadikan sebagai pedoman bagi pelaku usaha jasa keuangan, seperti Peraturan Otoritas Jasa Keuangan Nomor: 1/POJK.07/2013 tentang Perlindungan Konsumen Sektor Jasa Keuangan, Peraturan Otoritas Jasa Keuangan Nomor: 1/ POJK.07/2014 tentang Lembaga Alternatif Penyelesaian Sengketa di Sektor Jasa Keuangan dan SEOJK Nomor: 2/SEOJK.07/ 2014 tentang

5 https://business-law.binus.ac.id/2017/06/18/kejahatan-perbankan-dan-pelanggaranperbankan/. Diakses Pukul 10.22 Wib, 26 November 2019. 
Pelayanan dan Penyelesaian Pengaduan Konsumen pada Pelaku Usaha Jasa Keuangan. ${ }^{6}$

\section{b. Konsep Kejahatan Ekonomi di Bidang Perbankan}

Kejahatan ekonomi dapat dibagi menjadi dua, yaitu dalam arti sempit dan arti luas. Arti sempit, istilah economic crimes (kejahatan ekonomi) apabila dilihat dari substansi pasal 1 Undang-Undang No. 7 Drt. 1955 dapat dimasukkan ke dalam pengertian tindak pidana ekonomi. Hal ini disebabkan undang-undang tersebut secara substansi hanya memuat ketentuan yang mengatur sebagian kecil dari kegiatan ekonomi secara keseluruhan.Di luar batasan-batasan tersebut, perbuatan apa pun yang melanggarperaturan perundang-undangan dan merugikan perekonomian Indonesia tidak dapat dinamakan kejahatan ekonomi. ${ }^{7}$

Arti luas, kejahatan ekonomi, diatur di dalam maupun di luar Undang-Undang No. 7 Drt. 1955. Kejahatan ekonomi di bidang perbankan, sebagai suatu bentuk perbuatan yang melanggar peraturan perundang-undangan dalam bidang perekonomian dan bidang keuangan, merupakan bagian dari kejahatan ekonomi. Menurut Moch. Anwar dalam bukunya yang berjudul Tindak Pidana di Bidang Perbankan membedakan pengertian tindak pidana perbankan dengan tindak pidana di bidang perbankan. Perbedaan tersebut didasarkan pada perlakuan peraturan terhadap perbuatan-perbuatan yang telah melanggar hukum yang berhubungan dengan kegiatan bank dalam menjalankan usahanya. ${ }^{8}$

\section{c. Penyelesaian Sengketa Perbankan Berkaitan Dengan Perlindungan Konsumen}

Peraturan Otoritas Jasa Keuangan Nomor: 1/POJK.07/2013 tentang Perlindungan Konsumen Sektor Jasa Keuangan yang selanjutnya akan disingkat POJK No.1/pojk.07/2013, terdapat pengaturan mengenai penanganan pengaduan serta penyelesaian sengketa konsumen, yang selanjutnya dalam Surat Edaran Otoritas Jasa Keuangan Nomor 2/SE0JK.07/2014 tentang Pelayanan dan Penyelesaian Pengaduan Konsumen Pada Pelaku Usaha Jasa Keuangan, yang selanjutnya akan disingkat SEOJK No.2/ SOJK.07/2014, berisikan ketentuan yang mengatur mengenai pelayanan dan penyelesaian pengaduan konsumen pada pelaku usaha jasa keuangan. Surat Edaran Otoritas Jasa Keuangan Nomor 2/SEOJK.07/2014, dalam Bab II angka (1) mendefinisikan pengertian dari pengaduan adalah ungkapan ketidakpuasan Konsumen yang disebabkan oleh adanya kerugian dan/atau potensi kerugian finansial pada Konsumen yang diduga karena kesalahan atau kelalaian Lembaga Jasa Keuangan. Mekanisme mengenai

6 Rati Maryani Palilati. Perlindungan Hukum Konsumen Perbankan Oleh Otoritas Jasa Keuangan. Jurnal Ius Kajian Hukum dan Keadilan, Vol. IV (3), 2016, hal. 53.

7 Mardjono Reksodiputro, Hukum Positif Mengenai Kejahatan Ekonomi dan Perkembangannya di Indonesia, Alumni: Bandung, 1987, hal. 326.

8 Rachmawati Apriliana Puspitasari dan Nyoman Satyayudha Dananjaya. Op.Cit., hlm. 3. 
pelayanan dan penyelesaian pengaduan konsumen pada pelaku usaha jasa keuangan telah diatur dalam POJK No.1/pojk.07/2013 dan SEOJK No.2/SOJK.07/2014. Selain itu mengenai Penyelesaian pengaduan juga telah di atur jelas dalam ketentuan pada Pasal 38 huruf c POJK No.1/pojk.07/2013 dan lebih rinci pada Bab III SEOJK No.2/SOJK.07/2014.

Ketentuan Pasal 38 huruf c POJK No.1/pojk.07/2013 mewajibkan pelaku usaha jasa keuangan setelah menerima pengaduan, untuk menyampaikan pernyataan maaf dan menawarkan ganti rugi (redress/remedy) atau perbaikan produk dan atau layanan, jika pengaduan Konsumen benar dan pada Bab III SEOJK No.2/SOJK.07/2014 angka 1 menjelaskan lebih rinci bahwa bentuk pernyataan maaf tersebut dilakukan secara tertulis, yang pada kenyataannya pernyataan maaf tersebut oleh konsumen lazimnya hanya berupa pernyataan maaf secara lisan olehpihak Pelaku Usaha Jasa Keuangan dalam hal ini pihak perbankan.

Hal tidak dapat mencapai kata sepakat dalam pengaduan tersebut di atas, maka konsumen dapat menyelesaikan sengketanya pada lembaga alternatif penyelesaian sengketa dengan dapat difasilitasi oleh Otoritas Jasa Keuangan. Otoritas Jasa Keuangan dalam Pasal 4 POJK No. 1/POJK.07/2014 menetapkan lembaga alternatif yang dimuat dalam daftar lembaga alternatif penyelesaian sengketa meliputi :9

a. Mempunyai layanan penyelesaian Sengketa paling kurang berupa:

1. Mediasi;

2. Ajudikasi; dan

3. Arbitrase.

b. Mempunyai peraturan yang meliputi:

1. Layanan penyelesaian Sengketa;

2. Prosedur penyelesaian Sengketa;

3. Biaya penyelesaian Sengketa;

4. Jangka waktu penyelesaian Sengketa;

5. Ketentuan benturan kepentingan dan afiliasi bagi mediator, ajudikator, dan arbiter; dan

6. Kode etik bagi mediator, ajudikator, dan arbiter;

c. Menerapkan prinsip aksesibilitas, independensi, keadilan, dan efisiensi dan efektifitas dalam setiap peraturannya;

d. Mempunyai sumber daya untuk dapat melaksanakan pelayanan penyelesaian Sengketa; dan

e. Didirikan oleh Lembaga Jasa Keuangan yang dikoordinasikan oleh asosiasi dan/atau didirikan oleh lembaga yang menjalankan fungsi self regulatory organization.

9 Lihat Pasal 4, Peraturan Otoritas Jasa Keuangan Nomor 1/P0JK.07/2014 tentang Lembaga Alternatif Penyelesaian Sengketa di Sektor Jasa Keuangan. 
Lembaga Alternatif Penyelesaian Sengketa Perbankan Indonesia adalah Lembaga Alternatif Penyelesaian Sengketa Perbankan Indonesia yang didirikan oleh Asosiasi di bidang Perbankan, yakni Perhimpunan Bank Nasional (PERBANAS), Himpunan Bank Milik Negara (HIMBARA), Asosiasi Bank Pembangunan Daerah (ASBANDA), Asosiasi Bank Syariah Indonesia (ASBISINDO), Perhimpunan Bank-Bank Internasional Indonesia (PERBINA), dan Perhimpunan Bank Perkreditan Rakyat Indonesia (PERBARINDO) pada tanggal 28 April 2015.10

Dengan demikian, dapat disimpulkan bahwa penyelesaian sengketa perbankan, terdapat dua mekanisme penyelesaian sengketa perbankan, yaitu penyelesaian sengketa secara internal (internal dispute resolution) dan penyelesaian sengketa secara eksternal (external dispute resolution). Terkait dengan Internal dispute resolution, OJK mewajibkan para pelaku usaha jasa keuangan, termasuk lembaga perbankan, untuk memiliki dan melaksanakan mekanisme pelayanan dan penyelesaian pengaduan bagi konsumen sebagai yang diatur dalam Pasal 32 ayat (1) POJK No. 1/POJK.07/2013 tentang Perlindungan Konsumen Jasa Keuangan. Apabila perselisihan/sengketa antar nasabah dengan bank tidak bisa diselesaikan secara internal, maka berdasarkan kesepakatan kedua belah pihak, perselisihan/sengketa tersebut bisa diselesaikan melalui external dispute resolution.

External dispute resolution bisa berupa penyelesaian melalui peradilan (litigation) dan alternatif penyelesaian sengketa (Alternative Dispute Resolution) seperti mediasi, adjudikasi dan arbitrase. Hal ini sesuai dengan peraturan OJK No. 1/P0JK.07/2014 tentang Lembaga Alternatif Penyelesaian Sengketa Di Sektor Jasa Keuangan yang mengatur bahwa pengaduan wajib diselesaikan terlebih dahulu oleh lembaga jasa keuanagan. Jika tidak mencapai kesepakatan, konsumen dan lembaga jasa keuangan dapat melakukan penyelesaian sengketa di luar pengadilan atau melalui pengadilan (Pasal 2). Saat ini Lembaga Alternatif Penyelesaian Sengketa Perbankan Indonesia (LAPSPI) diberikan kewenangan menyelesaikan sengketa perbankan.

\section{d. Upaya Otoritas Jasa Keuangan dalam Perlindungan Hukum kepada Konsumen Kejahatan Perbankan}

Pasal 28 Undang-Undang No. 21 Tahun 2011 tentang Otoritas Jasa Keuangan, mengatur mengenai perlindungan konsumen dan masyarakat Otoritas Jasa Keuangan berwenang melakukan tindakan pencegahan kerugian konsumen dan masyarakat yang meliputi : ${ }^{11}$

a) Memberikan informasi dan edukasi kepada masyarakat atas karakteristik sektor jasa keuangan, layanan, dan produknya;

10 Rati Maryani Palilati. Op.Cit., . hlm. 55.

11 Lihat Pasal 28, Undang-Undang Nomor 21 Tahun 2011 tentang Otoritas Jasa Keuangan. 
b) Meminta Lembaga Jasa Keuangan untuk menghentikan kegiatannya apabila kegiatan tersebut berpotensi merugikan masyarakat; dan

c) Tindakan lain yang dianggap perlu sesuai dengan ketentuan peraturan perundangundangan di sektor jasa keuangan.

Selain upaya pencegahan pelanggaran, dalam Pasal 29 Undang-Undang No. 21 Tahun 2011 tentang Otoritas Jasa Keuangan, terdapat beberapa instrument untuk pelayanan pengaduan konsumen atas pelanggaran yang dilakukan oleh pelaku usaha, yakni meliputi :12

a) Menyiapkan perangkat yang memadai untuk pelayanan pengaduan konsumen yang dirugikan oleh pelaku di lembaga jasa keuangan.

b) Membuat mekanisme pengaduan konsumen yang dirugikan oleh pelaku di lembaga jasa keuangan; dan

c) Memfasilitasi penyelesaian pengaduan konsumen yang dirugikan oleh pelaku di lembaga jasa keuangan sesuai dengan peraturan perundang-undagan di sektor jasa keuangan.

Rumusan-rumusan tersebut diatas mengindikasikan peran Otoritas Jasa Keuangan dalam sistem hukum perlindungan konsumen tidak terbatas hanya dengan memfasilitasi perlindungan konsumen yakni menampung dan menjadi lembaga mediasi tetapi juga menjadi lembaga yang berpihak kepada konsumen dan masyarakat dalam bentuk kegiatan pembelaan hukum. Bentuk-bentuk perlindungan yang dilakukan oleh Otoritas Jasa Keuangan meliputi perlindungan dalam upaya pencegahan terjadinya pelanggaran dan pemulihan hak-hak konsumen apabila konsumen mengalami kerugian.

\section{PENUTUP}

Berdasarkan penjelasan yang telah dipaparkan di atas, maka dapat disimpulkan bahwa mekanisme penyelesaian sengketa perbankan berkaitan dengan perlindungan konsumen yakni dapat melalui dua mekanisme penyelesaian sengketa perbankan, yaitu penyelesaian sengketa secara internal (internal dispute resolution) dan penyelesaian sengketa secara eksternal (external dispute resolution).Internal dispute resolution, $0 \mathrm{JK}$ mewajibkan para pelaku usaha jasa keuangan, termasuk lembaga perbankan, untuk memiliki dan melaksanakan mekanisme pelayanan dan penyelesaian pengaduan bagi konsumen. External dispute resolution bisa berupa penyelesaian melalui peradilan (litigation) dan alternatif penyelesaian sengketa (Alternative Dispute Resolution) seperti mediasi, adjudikasi dan arbitrase.

12 Lihat Pasal 29. Ibid. 


\section{DAFTAR PUSTAKA}

Inosentius Samsul. 2013. Perlindungan Konsumen Jasa Keuangan Pasca Pembentukan Otoritas Jasa Keuangan (OJK). Jurnal Negara Hukum, Vol. 4 No. 2.

Mardjono Reksodiputro. 1987. Hukum Positif Mengenai Kejahatan Ekonomi dan Perkembangannya di Indonesia. Alumni: Bandung.

Rachmawati Apriliana Puspitasari dan Nyoman Satyayudha Dananjaya. 2014. Perlindungan Terhadap Korban Kejahatan Ekonomi di Bidang Perbankan. Kertha Wicara: Journal Ilmu Hukum, Vol. 3 No.2.

Rati Maryani Palilati, Perlindungan Hukum Konsumen Perbankan Oleh Otoritas Jasa Keuangan. 2016. Jurnal Ius Kajian Hukum dan Keadilan, Vol. IV No.3.

Undang-Undang Nomor 21 Tahun 2011 tentang Otoritas Jasa Keuangan

Peraturan Otoritas Jasa Keuangan Nomor 1/POJK.07/2014 tentang Lembaga Alternatif Penyelesaian Sengketa di Sektor Jasa Keuangan.

https://business-law.binus.ac.id/2017/06/18/kejahatan-perbankandanpelanggaran-perbankan/. Diakses Selasa 26 November 2019. 


\section{PEDOMAN PENULISAN \\ JURNAL PRANATA HUKUM}

1. Naskah bersifat orisinil, baik berupa hasil riset atau tinjauan atas suatu permasalahan hukum yang berkembang di masyarakat (artikel lepas), dimungkinkan juga tulisan lain yang dipandang memberikan kontribusi bagi pengembangan ilmu hukum.

2. Penulisan terdiri atas beberapa bab penulisan hasil penelitian terdiri dari $3 \mathrm{BAB}$, yaitu ;

BAB I. PENDAHULUAN (Latar Belakang dan Rumusan Masalah) BAB II. PEMBAHASAN (Kerangka Teori dan Analisis), dan BAB III. PENUTUP (Kesimpulan dan Saran).

3. Tulisan menggunakan bahasa indonesia maupun bahasa inggris yang memenuhi kaidah bahasa yang baik dan benar,tulisan menggunakan bahasa indonesia disertai abstrak dalam bahasa inggris (200 kata) dan Kata kunci, ketentuan ini berlaku sebaliknya.

4. Setiap kutipan harus menyebutkan sumbernya dengan format footnote. Sumber kutipan harus memuat nama pengarang, tahun penerbitan, judul buku, nama penerbit, kota penerbit, dan halaman. Contoh : Bagir Manan. 1994. Hubungan Antara Pemerintah Pusat dan Daerah Menurut UUD 1945. Pustaka Sinar Harapan. Jakarta. 1994, hlm. 19. Untuk artikel dari internet dengan susunan: nama penulis, judul tulisan digaris bawah, alamat website, waktu download/unduh.

5. Naskah harus disertai dengan daftar pustaka atau referensi ,terutama yang digunakan sebagai bahan acuan langsung. Daftar pustaka dan referensi bersifat alfabetis dengan format; nama pengarang, judul buku, nama penerbit, kota terbit, dan tahun penerbitan. Contoh: Bagir Manan. 1994. Hubungan Antara Pemerintah Pusat dan Daerah Menurut UUD 1945. Pustaka Sinar Harapan. Jakarta.

6. Panjang tulisan antara 15-25 halaman, font cambria dengan 1,15 spasi. Dalam hal hal tertentu berlaku pengecualian panjang tulisan.

7. Naskah disertai nama lengkap penulis, alamat e-mail dan lembaga tempat berafiliasi saat ini, dan hal lain yang dianggap penting. 
Jurnal PRANATA HUKUM dimaksudkan sebagai media komunikasi, edukasi, dan informasi ilmiah bidang ilmu hukum khususnya, dan ilmu sosial pada umumnya. Sajian dan kemasan diupayakan komunikatif melalui bahasa ilmiah.

Redaksi mengundang semua elemen masyarakat baik civitas akademika, praktisi, lembaga masyarakat, maupun perorangan yang berminat terhadap bidang hukum untuk berpartisipasi mengembangkan gagasan, wawasan, dan pengetahuan melalui tulisan untuk dimuat dalam jurnal ini.

Melalui PRANATA HUKUM diharapkan terjadi proses pembangunan dan pengembangan bidang hukum sebagai bagian penting dari rangkaian panjang proses memajukan masyarakat bangsa.
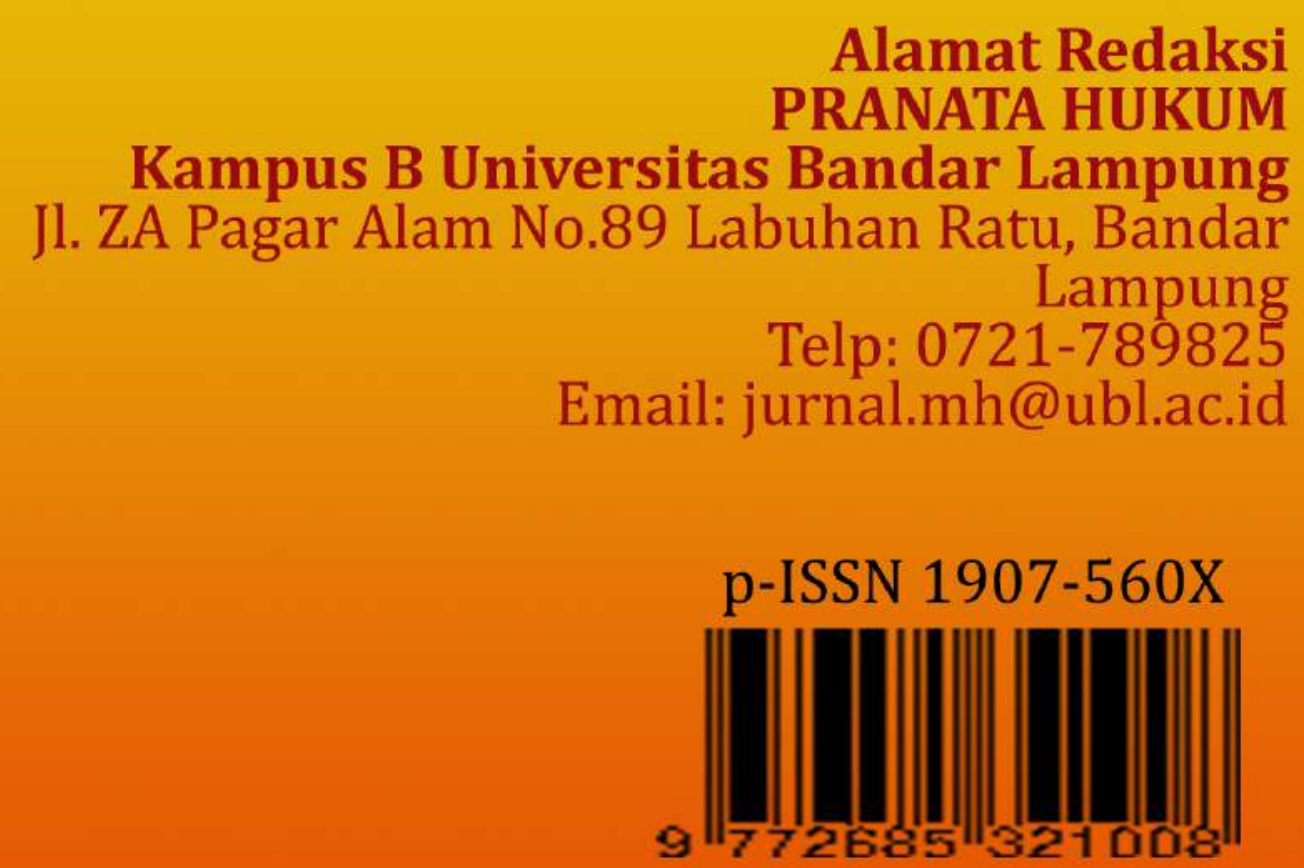